*УДК 657

Голячук Н.В., к.е.н., доцент

Луцький національний технічний університет

\title{
УДОСКОНАЛЕННЯ ОБЛІКУ ФІНАНСОВИХ РЕЗУЛЬТАТІВ ДІЯЛЬНОСТІ ЛІСОГОСПОДАРСЬКИХ ПІДПРИЄМСТВ
}

У статті розглянуто питання організації облікового процесу на підприємствах лісового господарства та формування їх фінансових результатів; проаналізовані визначення науковців та запропоноване власне бачення відображення фінансових результатів в обліку.

Ключові слова: інформація, фінансові результати, облік, рахунки.

Holiachuk N.

\section{MPROVEMENT OF ACCOUNTING OF FINANCIAL RESULTS OF ACTIVITIES OF FORESTRY ENTERPRISES}

The process of determining financial results as an integral part of the flow of accounting and management information, without involving all the economic cycles of the enterprise is impossible, is important to distinguish and regulate the flows of information about all accounting objects.

The proposed scheme of organization of accounting of financial results provides strengthening of control over activity of structural divisions of forestry enterprises.

The process of exchanging information between different users is quite complicated. Therefore, the important issue of providing the company management with complete, truthful and impartial information for making management decisions is to create a model of accounting and analytical support for the formation of financial results of the forestry enterprise.

Business management requires systematic information on operating, financial and investment activities and the associated costs, revenues and results. That is why there is a need to revise the methodology and organization of the formation of financial results of economic entities.

After analyzing the research and proposals of scientists, we propose to use analytical subaccounts in the account 79 «Financial results».

Clearly differentiating results by type of activity is of fundamental importance for assessing the financial and economic activity of the enterprise, is strategic development, which proves the feasibility and importance of the distribution of income, expenses and financial results in terms of operating, financial, investment activities and emergency events. Such information will be useful to the management of the enterprise

\footnotetext{
* Голячук Н.В.
} 
for evaluating the effectiveness of financial and economic activities, as well as for making sound management decisions.

Key words: information, financial results, accounting, accounts.

Голячук Н.В

$$
\begin{gathered}
\text { СОВЕРШЕНСТВОВАНИЕ УЧЕТА } \\
\text { ФИНАНСОВЫХ РЕЗУЛЬТАТОВ ДЕЯТЕЛЬНОСТИ } \\
\text { ЛЕСОХОЗЯЙСТВЕННЫХ ПРЕДПРИЯТИЙ }
\end{gathered}
$$

В статье рассмотрены вопросы организации учетного процесса на предприятиях лесного хозяйства и формирование их финансовых результатов; проанализированы определения ученых и предложено собственное видение отражения финансовых результатов в учете.

Ключевые слова: информация, финансовые результаты, учет, счета.

Постановка проблеми у загальному вигляді та іï зв'язок 3 важливими науковими та практичними завданнями. Управління підприємствами лісового господарства характеризується великими обсягами інформації, яку необхідно щоденно обробляти, складною системою обліку, контролю та аналізу отриманої інформації, складними інформаційними зв'язками всередині підприємства та із зовнішнім середовищем. Тому важливою проблемою є розробка на підприємстві раціонального потоку інформації, складовими якого $є$ такі етапи: виявлення інформаційних потреб з боку споживачів та повне їх задоволення; відповідність способів задоволення потреб запитам споживачів; відображення в системі інформації облікових даних про використання всіх видів ресурсів в процесі господарської діяльності; усунення дублювання даних первинної документації; швидкість обробки і передачі інформації для оперативного управління та складання звітності лісогосподарського підприємства.

Аналіз останніх досліджень, у яких започатковано вирішення проблеми. Вагомий внесок у теоретичні дослідження проблем обліку фінансових результатів зробили вітчизняні вчені-економісти Власова Н.О., Вороніна О.О., Карп’як Я.С., Костенко Ю.О., Левицька О.О., Лежненко Л.І., Макаренко А., Олійничук О.І., Прохар Н.В., Ратушна О.П., Скрипник М.С., Труфіна Ж.С.

Метою статті $\epsilon$ необхідність удосконалення обліку формування фінансових результатів лісогосподарських підприємств 3 
урахуванням їх інформаційних потреб, а також нормативного забезпечення бухгалтерського обліку.

Виклад основного матеріалу дослідження з повним обгрунтуванням отриманих наукових результатів. Процес визначення фінансових результатів, як невід'ємна частина потоку облікової та управлінської інформації, без залучення всіх економічних циклів підприємства $€$ неможливим, тому важливого значення набуває саме розмежування та регламентація потоків інформації про всі об'єкти обліку.

Обмін обліковою та лісівничою інформацією між структурними підрозділами підприємства лісового господарства для визначення фінансових результатів діяльності показаний на рис. 1. Процес використання інформації опишемо детальніше. Економіст по нормуванню праці займається розрахунком норм виробітку та розцінок по видах робіт. Оскільки лісове господарство це досить специфічна галузь народного господарства, то тарифні ставки для розрахунку розцінок по видах робіт залежать від виду робіт та середнього об'єму хлиста відповідної породи дерев (як правило породи дерев поділяються на види: твердолистяні породи, хвойні та м'яколистяні породи) в залежності від їх діаметру. Інформацію про породи дерев, їх об'єм, діаметр, висоту, тобто про сортиментну структуру надає інженер лісового господарства. Розраховані розцінки передаються в бухгалтерію лісництв. Від лісничого чи майстра лісу в бухгалтерію поступає інформація про об'єм виконаних лісосічних робіт на рубках головного користування. За виконану роботу на основі розцінок працівникам нараховується заробітна плата і ця інформація передається в центральну бухгалтерію бухгалтеру по оплаті праці, де проводиться зведення даних по всіх лісництвах та апарату управління і складається зведена звітність для головного бухгалтера. Бухгалтер лісництва проводить також аналітичний облік виконаних лісосічних робіт і дані передає бухгалтеру по обліку руху лісопродукції, який в свою чергу складає зведену звітність по всіх лісництвах і передає дані головному бухгалтеру. Для виплати заробітної плати інформація передається до бухгалтера по обліку розрахункових операцій та касира, а потім зведені дані до головного бухгалтера. Інженер лісового господарства складає звітність по рубках головного користування на основі 
інформації, що надходить від лісничих і передає їі головному лісничому. Головні спеціалісти держлісгоспу подають зведену інформацію директору держлісгоспу, а потім до обласного об'єднання лісового господарства.

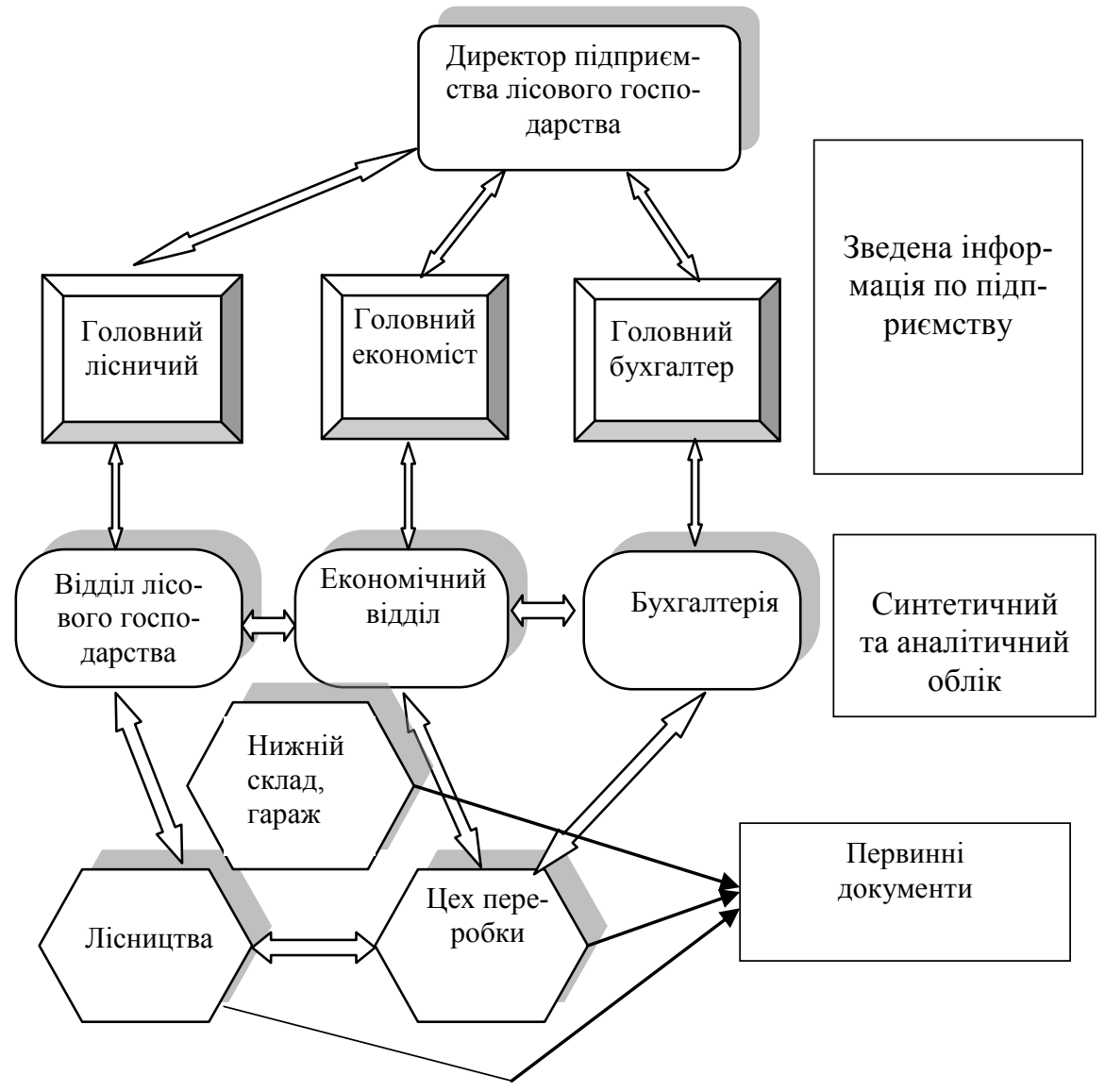

Рис. 1. Схема організації облікового процесу на підприємствах лісового господарства*

*Розроблено автором

Запропонована схема організації обліку фінансових результатів забезпечує посилення контролю за діяльністю структурних під- 
розділів лісогосподарських підприємств. Інформація 3 первинних та зведених документів підлягає обробці безпосередньо в лісництвах, цеху переробки, допоміжних підрозділах. Контроль інформації про доходи, витрати та фінансові результати в аналітичному та синтетичному розрізах покладено на керівників структурних підрозділів. Контрольні повноваження головного бухгалтера, головного економіста, головного інженера полягають у перевірці регістрів синтетичного та аналітичного обліку й формуванні внутрішньої та зовнішньої звітності. Тоді як головний лісничий й керівник підприємства здійснюють загальний контроль результатів діяльності та прийняття рішень 3 метою поточного й перспективного управління підприємством [1].

Процес обміну інформацією між різними користувачами $€$ досить складним. Тому важливим питанням забезпечення керівництва підприємства повною, правдивою та неупередженою інформацією для прийняття управлінських рішень є створення моделі обліково-аналітичного забезпечення формування фінансових результатів діяльності лісогосподарського підприємства (рис. 2).

Концептуальним підходом до побудови такої моделі $є$ іï структура, яка складається 3 блоків, що відповідають процесам виробничої діяльності лісогосподарського підприємства: виробництво, збут. Особливістю діяльності лісогосподарського підприємства є тривалість операційного циклу, який триває декілька десятків років. Процес виробництва складається 3 таких етапів : посадка лісу - вирощування - догляд за лісом - експлуатація стиглих лісових насаджень. Процес постачання на лісогосподарських підприємствах складається з придбання інструментів, пального, запасних частин для машин та механізмів, задіяних у процесі виробництва. Тому в нашій моделі окремо не виділяється блок постачання як процес виробничої діяльності підприємства.

Інформаційна модель забезпечення інформацією процесу управління підприємством складається 3 основних інформаційних блоків внутрішнього середовища: виробництва та збуту. Зв'язок 3 зовнішнім середовищем відбувається через інформаційні зв'язки 3 постачальниками та покупцями. 


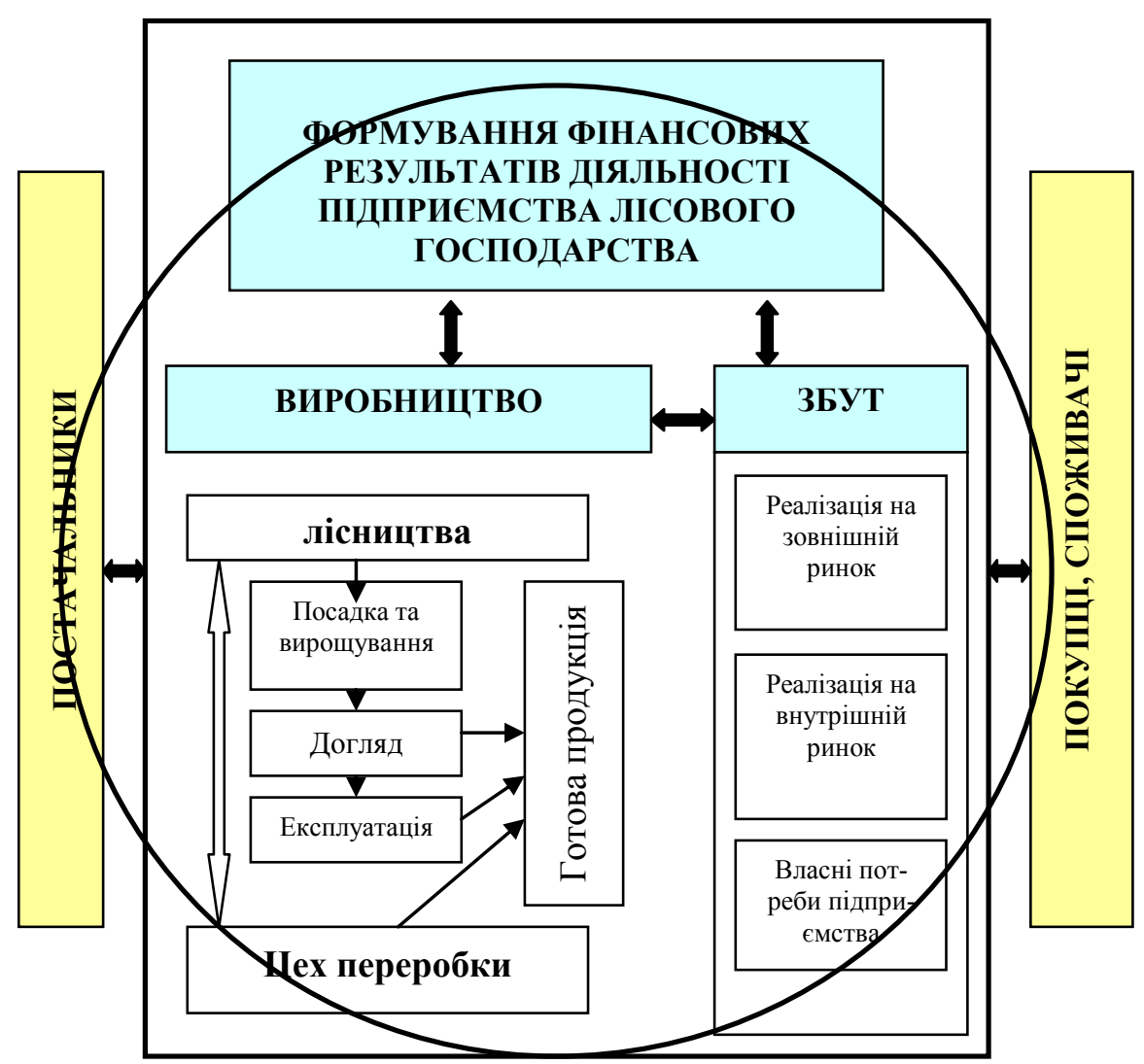

Рис. 2. Модель формування фінансових результатів діяльності лісогосподарського підприємства*

*Розроблено автором

Ці блоки взаємопов’язані між собою та несуть потоки інформації, які характеризуються напрямком та належністю до конкретних функцій управління, відношенням до процесу виробництва та збуту готової продукції. Інформаційні потоки несуть інформацію про плани діяльності підприємства, про наукові розробки, нові 
технології, юридичну, комерційну та іншу інформацію. А блоки виробництва та збуту подають фактична інформація про діяльність лісництв (лісовідтворення, лісозбереження, експлуатація лісових насаджень, наявність лісопродукції на франко-верхньому та франко-нижньому складах, тощо), цеху переробки лісопродукції (наявність сировини, готової продукції), про збут готової продукції (інформація про наявність та відвантаження готової лісопродукції). Таким чином, модель формування фінансових результатів діяльності лісогосподарського підприємства на основі інформаційних потоків дозволить розв'язувати функціональні задачі управління, забезпечувати керівництво повною та достовірною інформацією про виробничі процеси та формувати фінансову звітність.

За ринкових умов суттєво зростає роль і значення фінансових результатів в розвитку підприємства, докорінно змінюється як порядок, так і обгрунтованість їх визначення в системі фінансового та внутрішньогосподарського обліку. Управління підприємством вимагає систематичної інформації про операційну, фінансову та інвестиційну діяльність та пов'язаних 3 такою діяльністю витрат, доходів і результатів. Саме тому, виникає необхідність перегляду методики та організації формування фінансових результатів господарюючих суб'єктів [2].

Скрипник М.С. в дисертаційному дослідженні зазначає, що методика фінансового обліку відповідно до чинних П(С)БО передбачає, що облік собівартості реалізованої продукції, доходів від реалізації готової продукції та фінансових результатів від іï реалізації ведеться узагальнено на синтетичних рахунках 901 «Собівартість реалізованої готової продукції», 701 «Дохід від реалізації готової продукції», 791 «Результат операційної діяльності». Проте цієї інформації недостатньо для задоволення потреб користувачів облікової інформації різних рівнів управління, яким необхідно визначати та обліковувати собівартість та доходи від реалізації за місцями виникнення доходу (цеху), групами та асортиментом продукції, а також категоріями покупців. Виходячи з цього, запропоновано вести облік доходів, витрат та фінансового результату від 
реалізації продукції 3 використанням аналітичних субрахунків. Деталізація субрахунку 791 «Результат операційної діяльності» за субрахунками першого, другого, третього та четвертого порядків дає можливість визначити найбільш прибуткові види готової продукції і вилучити з виробництва (або скоротити обсяг) малорентабельні [3].

Для вирішення завдання відображення фінансових результатів в обліку Олійничук О.І. пропонує введення відповідних аналітичних рахунків до рахунка 791 «Результат операційної діяльності», а саме: 7911 «Результат основної діяльності» і 7912 «Результат іншої операційної діяльності». Відображення господарських операцій на аналітичних рахунках 7911 і 7912 дозволить без додаткових трудових і часових затрат отримати інформацію стосовно результатів основної й іншої операційної діяльності, а також динаміки їх показників для забезпечення потреб ефективного менеджменту [4].

За переконанням Костенко Ю.О., аналіз шляхів удосконалення показав, що основними об'єктами удосконалення є рахунки 79 «Фінансові результати», 44 «Нерозподілені прибутки (непокриті збитки)», 73 «Інші фінансові доходи» та 71 «Інший операційний дохід». Найбільше пропозицій щодо удосконалення пов'язані 3 рахунком 79 «Фінансові результати». Більшість науковців пропонують використовувати більшу кількість субрахунків або змінити назви вже існуючим і додати нові. Такими шляхами вони пропонують невелювати основний недолік формування фінансового результату в Плані рахунків бухгалтерського обліку: на субрахунках 791 й 792 поєднані по два види діяльності підприємства на субрахунку 791 «Результат операційної діяльності» основна та інша операційна діяльність, а на субрахунку 792 «Результат фінансових операцій» інвестиційна й фінансова діяльність. Щодо рахунку 44 «Нерозподілені прибутки (непокриті збитки)», науковці пропонують використовування субрахунків для обліку за різними видами діяльності як прибутків так і збитків [5].

Труфіна Ж.С. при розробці робочого плану рахунків пропонує передбачати до субрахунку 791 «Результат операційної діяльності» субрахунки другого порядку: 791.1 «Результат основної дія- 
льності» та 791.2 «Результат іншої операційної діяльності». Це дасть можливість виявляти фінансові результати окремо від основної та іншої операційної діяльності, що необхідно для поглиблення аналізу структури фінансових результатів, розрахунку меж беззбитковості основної операційної діяльності, обгрунтування управлінських рішень, пов'язаних з CVP-аналізом [6].

Проаналізувавши дослідження та пропозиції науковців, пропонуємо використовувати аналітичні субрахунки до рахунка 79 «Фінансові результати»:

791 Результат операційної діяльності

791.1 Результат основної діяльності

791.11 Результат від реалізації лісопродукції

791.12 Результат від реалізації продукції лісопереробки

791.13 Результат від реалізації продукції побічного користування

Пропозиції щодо організації аналітичного обліку по субрахунках IV порядку наведено в табл. 1.

Таблиця 1

Пропозиції щодо організації аналітичного обліку до субрахунку

791.1 «Результат основної діяльності»*

\begin{tabular}{|c|c|c|c|}
\hline \multicolumn{4}{|c|}{ Аналітичні рахунки } \\
\hline код & IV порядок & код & V порядок \\
\hline 1 & 2 & 3 & 4 \\
\hline \multirow{5}{*}{791.111} & \multirow{5}{*}{$\begin{array}{c}\text { Результат від реаліза- } \\
\text { ції лісо продукції на } \\
\text { вітчизняному ринку }\end{array}$} & 791.1111 & Фанерний кряж \\
\hline & & 791.1112 & Пиловник \\
\hline & & 791.1113 & Баланси \\
\hline & & 791.1114 & Будівельний ліс \\
\hline & & 791.1115 & Інші \\
\hline
\end{tabular}


"Економічні науки". - Серія "Облік і фінанси". - Випуск 16 (61). - 2019.

Продовження табл.1

\begin{tabular}{|c|c|c|c|}
\hline 1 & 2 & 3 & 4 \\
\hline \multirow{5}{*}{791.112} & \multirow{5}{*}{$\begin{array}{c}\text { Результат від реаліза- } \\
\text { ції лісо продукції на } \\
\text { експорт }\end{array}$} & 791.1121 & Фанерний кряж \\
\hline & & 791.1122 & Пиловник \\
\hline & & 791.1123 & Баланси \\
\hline & & 791.1124 & Будівельний ліс \\
\hline & & 791.1125 & Інші \\
\hline \multirow{6}{*}{791.121} & \multirow{6}{*}{$\begin{array}{c}\text { Результат від реаліза- } \\
\text { ції продукції лісопе- } \\
\text { реробки на вітчизня- } \\
\text { ному ринку }\end{array}$} & 791.1211 & Дошки обрізні \\
\hline & & 791.1212 & Дошки не обрізні \\
\hline & & 791.1213 & Паркетні дошки \\
\hline & & 791.1214 & Піддони \\
\hline & & 791.1215 & Меблеві заготовки \\
\hline & & 791.1216 & Інші \\
\hline \multirow{6}{*}{791.122} & \multirow{6}{*}{$\begin{array}{c}\text { Результат від реаліза- } \\
\text { ції лісо продукції на } \\
\text { експорт }\end{array}$} & 791.1221 & Дошки обрізні \\
\hline & & 791.1222 & Дошки не обрізні \\
\hline & & 791.1223 & Паркетні дошки \\
\hline & & 791.1224 & Піддони \\
\hline & & 791.1225 & Меблеві заготовки \\
\hline & & 791.1226 & Iнші \\
\hline \multirow{6}{*}{791.131} & \multirow{6}{*}{$\begin{array}{c}\text { Результат від реаліза- } \\
\text { ції продукції лісопе- } \\
\text { реробки на вітчизня- } \\
\text { ному ринку }\end{array}$} & 791.1311 & Гриби \\
\hline & & 791.1312 & Ягоди \\
\hline & & 791.1313 & Березовий сік \\
\hline & & 791.1314 & Джеми \\
\hline & & 791.1315 & Повидло \\
\hline & & 791.1326 & Інші \\
\hline \multirow{6}{*}{791.132} & \multirow{6}{*}{$\begin{array}{c}\text { Результат від реаліза- } \\
\text { ції лісо продукції на } \\
\text { експорт }\end{array}$} & 791.1321 & Гриби \\
\hline & & 791.1322 & Ягоди \\
\hline & & 791.1323 & Березовий сік \\
\hline & & 791.1324 & Джеми \\
\hline & & 791.1325 & Повидло \\
\hline & & 791.1326 & Інші \\
\hline
\end{tabular}

*Розробка автора

Чітке розмежування результатів за видами діяльності має принципове значення для оцінки фінансово-господарської діяльності підприємства, його стратегічного розвитку, що доводить доцільність та важливість розподілу доходів, витрат і фінансових ре- 
зультатів в розрізі операційної, фінансової, інвестиційної діяльності та надзвичайних подій. Така інформація буде корисною керівництву підприємства для оцінки ефективності фінансовогосподарської діяльності, а також для прийняття обгрунтованих управлінських рішень.

Висновки. Отже, проведене дослідження порядку відображення в обліку фінансових результатів лісогосподарських підприємств, дозволило виділити бухгалтерські рахунки, в тому числі в аналітичному розрізі, які дозволяють повно і достовірно зафіксувати прибутки чи збитки отримало підприємство від реалізації видів лісопродукції, лісопереробки чи продукції побічного користування. Отримана таким чином інформація $є$ основою для прийняття управлінських рішень щодо виробництва та реалізації продукції (робіт, послуг) тощо.

1. Прохар Н.В., Ночовна Ю.О. Облік доходів, витрат і фінансових результатів: проблеми теорії та практики: монографія. Полтава: РВВ ПУЕТ. 2011. 257 с.

2. Лежненко Л.І. Облік і аудит формування фінансових результатів (на прикладі хлібопекарних підприємств України). - автореферат дис... на здобуття наукового ступеня к.е.н. зі спец. 08.00.09 - Бухгалтерський облік, аналіз та аудит (за видами економічної діяльності). ДВНЗ «Київський національний економічний університет імені Вадима Гетьмана». Київ, 2007. 21с.

3. Скрипник М.Є. Облік і аналіз фінансових результатів в управлінні виробничим підприємством. - автореферат дис... на здобуття наукового ступеня к.е.н. за спец. 08.00.09 - бухгалтерський облік, аналіз та аудит (за видами економічної діяльності). - Київський національний торговельно-економічний університет, Київ, 2014. 25c.

4. Олійничук О. І. Організаційно-методичні аспекти обліку фінансового результату операційної діяльності підприємств. Інноваційна економіка. 2010. №2 (16). C.114-120.

5. Костенко Ю. О. Шляхи удосконалення обліку фінансових результатів діяльності підприємства. Проблеми і перспективи розвитку підприємництва. 2016. № 3(2). C. 93-99.

6. Труфіна Ж.С. Облік і контроль формування фінансових результатів операційної діяльності підприємств: теорія, методика, організація. - автореферат дис... на здобуття наукового ступеня к.е.н. за спец. 08.00.09 - Бухгалтерський облік, аналіз та аудит (за видами економічної діяльності). Державна академія статистики, обліку та аудиту Держкомстату України. Київ. 2010. 23 с. 